\title{
Vernacular Publics and Political Modernity: Language and Progress in Colonial South India
}

\author{
RAMA SUNDARI MANTENA
}

\author{
University of Illinois at Chicago, USA \\ Email:rmantena@uic.edu
}

\begin{abstract}
The late-nineteenth century in India, usually scrutinized for the emergence of anti-colonial nationalist thought and politics, witnessed broader, and potentially more radical changes in the making and re-making of political subjectivities as articulated within burgeoning vernacular public spheres. Vernacular publics coalesced around the emergence of new communicative forms, the formation of voluntary and political associations, and the restructuring of literary communities. It is within this context I place the writings of Gidugu Venkata Ramamurti (1863-1940). He proclaimed at the turn of the twentieth century that Telugu as a language had to be reformed in order for it to become an appropriate medium for the newly emergent Telugu public spheres. Through his study of linguistics, his commitment to educational reform, and his study of Telugu language and literature, Ramamurti became the spokesperson for a new Telugu that would be able to traverse the boundaries of modern genres of writing that flourished in the colonial era. Fully immersed in linguistic theories of the day, Ramamurti's concerns were primarily with language reform and its centrality in the remaking of political subjectivities.
\end{abstract}

'In this era there is an important challenge facing us. There is no Telugu word for 'challenge,' nevertheless, the word, 'dhikaaramu' or defiance, comes close. For that reason, I am calling this era, 'dhikaara yugamu,' the age of defiance. In the past, society was divided between free people and the enslaved. Soon, the enslaved defied the power of the free and freed themselves. In the past, women were not allowed to be educated nor were they allowed to work. Now they are asking themselves why they were not considered more productive in society? These days, women are performing all kinds of work....Until recently, in most countries the wealthy held power. And now the poor are challenging the power of the rich'. ${ }^{1}$

${ }^{1}$ Gidugu Venkata Ramamurti (1992), 'Neti saahityam [New Literature]' in Sahitya Vyasalu [Essays on Literature], Hyderabad: Visalandhra Publishing House, p. 194. First published in 1933 . 


\section{Introduction}

The Telugu intellectual, Gidugu Venkata Ramamurti (1863-1940), writing in the early decades of the twentieth century, gives voice to radical changes that were under way in south Indian society. These changes can be aptly viewed as ushering in a new age of political modernity articulated in the burgeoning vernacular public sphere. ${ }^{2}$ Through a reading of Ramamurti's writings, this paper will address three distinct but interrelated concerns current at the turn of the twentieth century in south India. First will be considered the ways in which the emergent Telugu public sphere impacted the character of political modernity. ${ }^{3}$ Secondly, two arenas of historical research on nineteenth-century India have primarily centred on social reform activities (the formation of voluntary associations around societal ills) and articulations of political and cultural nationalisms. This paper asks how intellectuals of this period negotiated the pull from these dominant discourses between social reform's Enlightenment ideals of egalitarianism and universalism and nationalism's insistence on affective loyalties to territory and community. ${ }^{4}$ Finally, fully immersed in linguistic theories of the day, Ramamurti's concerns were primarily with language reform and its centrality in the remaking of political subjectivities. Indeed Ramamurti believed that language productively linked the individual with society at large. Therefore, his conception

${ }^{2}$ My conceptualization of the Telugu public sphere is indebted to the critically important work of Francesca Orsini (for the Hindi heartland), Bernard Bate (for Tamil) and Veena Naregal (for Marathi) in historically documenting and theorizing the rise of the vernacular public sphere in colonial India. See Veena Naregal (2001), Language Politics, Elites, and the Public Sphere: Western India under Colonialism. New Delhi: Permanent Black; Francesca Orsini (2002), The Hindi Public Sphere, I920-1940: Language and Literature in the Age of Nationalism. New York: Oxford University Press; Bernard Bate (2009), Tamil Oratory and the Dravidian Aesthetic: Democratic Practice in South India. New York: Columbia University Press; and Bernard Bate (2010), 'The Ethics of Textuality: The Protestant Sermon and the Tamil Public Sphere' in Anand Pandian and Daud Ali, eds, Ethical Life in South Asia. Bloomington: Indiana University Press, pp. 101-115.

${ }^{3}$ I take political modernity to refer to a broad set of changes brought about in the late-colonial period in India with regard to the transformation of political institutions, conceptions of political participation, and the formation of new political subjectivities that reconfigured discussions surrounding democratic citizenship.

${ }^{4}$ Partha Chatterjee's work on nationalism and its various compromises addresses these tensions in the two dominant discourses of the late nineteenth century. See Partha Chatterjee (1993), Nation and its Fragments: Colonial and Postcolonial Histories. Princeton: Princeton University Press. 
of language as fundamentally social was crucial in his articulations of the onset of political modernity in colonial India.

Ramamurti firmly believed in the march of progress and as a selffashioned modernist declared that the period he was living under was an age of defiance (dhikkaarayugamu), of contempt-in essence an age that was ushered in by capitalist modernity. There were many Telugu words in circulation at the time to refer to the new: adhunika, adhunaatana, neti, nava. These words have a range of meanings from modern, contemporary, new, of the times. Throughout the nineteenth century, customs and social practices came under increasing scrutiny and many Telugu intellectuals in the Madras Presidency made proclamations on the newness of the era. The movement of progress that propelled Telugu writers to think in terms of a new future also, by consequence, produced the constant nagging feeling of being left behind as time was progressing. Modernizers such as Ramamurti felt that if liberal institutions of modernity were not wholeheartedly embraced, Telugu language and society would not only be left behind but in effect would stagnate in isolation. The desire to join the progress of humankind was the desire for coevalness with what Ramamurti saw as the onset of a truly global universalism that embraced the emergent institutions of democratic citizenship.

The experience of modernity was felt in this deeply temporal wayof a constant movement forwards, all the while, providing a new perspective on the past. We may recall here Reinhart Koselleck's thoughts on modernity and its relation to the idea of the future. '[T] he more a particular time is experienced as a new temporality, as "modernity",' Koselleck writes, 'the more demands made on the future increase'. ${ }^{5}$ For Ramamurti, the new society would nurture the conditions for people to engage freely and meaningfully with past traditions, customs and literature. In an essay entitled Prajaa saahityam [People's Literature], Ramamurti asks, 'How long must they remain alienated from traditions they have inherited?'. ${ }^{6}$ Ramamurti passionately argues for a deeply democratic vision of the past in relation to the present-that the past should remain radically open for the population at large to freely engage with it. He believed

\footnotetext{
${ }^{5}$ Koselleck, Reinhart (1985). Futures Past: On the Semantics of Historical Time. Cambridge, Massachusetts: MIT Press, p. xxiv.

${ }^{6}$ Gidugu Venkata Ramaurti (1992), 'Prajaa saahityam [People's Literature] in Sahitya Vyasalu [Essays on Literature]. Hyderabad: Visalandhra Publishing House, p. 103. First published in 1933 .
} 
wholeheartedly that language and region should not remain the exclusive property of the few. He then proclaims that Telugu people would be able to propel themselves forward and define the future of their own making only after gaining an understanding of their pasts. The feeling of the temporal movement of progress that we glimpse in Ramamurti's essays on newness and on people's literature show his deep commitment to the democratic possibilities of language in the newly emergent public sphere. Ramamurti's views on education, a call for people's literature, and a call to embrace modernity show his broader commitment to building public sphere institutions for participatory democracy.

At the centre of my inquiry into Ramamurti's writings is necessarily an understanding of the nature of modernity, which I hope to tease apart and, ultimately, come to an understanding of the experience of modernity that Telugu intellectuals were trying to capture in their writings. Habermas's classic description of 'modernization' defines it as 'a bundle of processes that are cumulative and mutually reinforcing: to the formation of capital and the mobilization of resources; to the development of the forces of production and the increase in the productivity of labour; to the establishment of centralized political power and the formation of national identities; to the proliferation of rights of political participation, of urban forms of life, and of formal schooling; to the secularization of values and norms; and so on'. ${ }^{7}$ Habermas insists that this theory of modernization is powerful and compelling precisely because it dissociates modernity from its European origins and stylizes it into what he calls a 'spatio-temporally neutral model'. This model of modernity as it is delinked from the conditions of its historical origins then has universalist applicability.

Sudipta Kaviraj provides a revised definition of modernity by disaggregating all its complexities particular to the historical conditions of colonial India: 'the phenomenon called modernity is not a single, homogeneous process, but a combination of several processes which can be isolated and distinguished. When we are talking about modernity, we are talking about a number of processes of social change which can be studied, or analysed independently of each othersuch as, capitalist industrialization, the increasing centrality of the state in the social order (Foucault's 'governmentality'), urbanization, sociological individuation, secularization in politics and ethics, vast

\footnotetext{
${ }^{7}$ Habermas, Jurgen (1990). The Philosophical Discourse of Modernity: Twelve Lectures. Cambridge, Massachusetts: MIT Press, p. 2.
} 
changes in the organization of family and intimacy, changes in the field of culture'. ${ }^{8}$ Whereas it seems overwhelming to make sense of all the 'bundle' of changes that both Habermas and Kaviraj invoke under one rubric, modernity as a conceptual term retains its utility in its complexity. The universalist dimensions of modernity that Habermas draws attention to, and Kaviraj's insistence on the need to examine the multiple processes of social change implied by modernity, are both critical for understanding the broad social and political changes that characterized the period. Colonial modernity has often been used to describe the hybrid forms of modernity or even at times incomplete forms of modernity as a way to flag the unequal relations between the colony and the metropole under colonial rule. Moreover, to escape the most troubled aspect of colonial modernity-its earlier conceptualization as derivative or imitative-one needs to embrace a plural conception of modernities. ${ }^{9}$ This conception opens up the irreducible plurality of modernities and acknowledges that there is no singular global march towards achieving a Euro-American modernity (what a conception of a singular modernity implies).

This paper is an attempt to join in this effort to pluralize modernities and in particular to examine the complexity of political modernity. Therefore, rather than view the field of culture as distinct from the field of politics, I suggest a broader cultural-political framework which structures the conditions for the proliferation of political subjectivities shaping a particular experience of modernity. The multiple sites within which processes of social change were unfolding in colonial India must be attended to in outlining a broad cultural frameworkone that encompasses the emergence of new communicative forms, the formation of associations for the critique of social customs/practices, the challenging of social structures of inequality, the restructuring of literary communities, and, finally, the formation of political associations. In nineteenth-century India, the formation of vernacular public spheres occasioned and conditioned the proliferation of political subjectivities. New communicative forms through the expansion of print media (such as journals, newspapers and school textbooks) as

${ }^{8}$ See Sudipta Kaviraj, Draft of Paper presented at the Roundtable discussion for the Pembroke Seminar (at Brown University) on 'Temporalities' directed by Rey Chow in 2005, p. 9.

${ }^{9}$ Chatterjee, Partha (200o). 'Our Modernity', The Present History of West Bengal: Essays in Political Criticism. New Delhi: Oxford University Press, 1997 and Dipesh Chakrabarty, Provincializing Europe: Postcolonial Thought and Historical Difference. Princeton: Princeton University Press. 
well as voluntary associations serving as organs for publicly turned activism were indeed geared towards the new 'middling classes'. ${ }^{10}$ Bernard Bate, anthropologist of south India, argues that schools and the printing press were taken up by a wider set of actors (cutting across class and caste distinctions) in the formation of entirely new modes of agency and political subjectivity. His conception of the uniqueness of this new type of public-ness is pertinent: 'That turning toward everyone, a turning to and calling to all, embodied a new ethic that had a great deal to do with the production of the ethical universe of strangers that we call the modern public sphere'. ${ }^{11}$ The entrance of new actors and the articulation of new modes of agency brought into being a new 'ethical universe of strangers' that also allowed for new ways of questioning existing communicative and cultural practices as well as enabling crucial shifts in cultural and political hierarchies. Within this context, language as an object of reform might seem unusual when there were more obvious societal inequities such as caste discrimination or gender inequality both of which became primary objects of social reform activity. However, when Gidugu Venkata Ramamurti viewed the state of the Telugu language at the end of the nineteenth century, after a century of print technology had given rise to new communicative modes, he was confronted by disparate language practices-some that pre-dated colonial rule and others that were new. The surveying of language practices in the Telugu public sphere led him to proposals for a written standard of Telugu. ${ }^{12}$ Ramamurti insisted that reforming language was as central if not more to the molding of new political subjectivities as confronting other existing social hierarchies.

Ramamurti proclaimed at the turn of the twentieth century that Telugu as a language had to be reformed in order for it to become an appropriate medium for the newly emergent Telugu public spheres. Through his study of linguistics (he wrote a grammar of a little-known language of the Sora ${ }^{13}$ tribe spoken on the south-eastern coast of Orissa), his commitment to educational reform, and his study of

${ }^{10}$ Orsini, The Hindi Public Sphere, p. 18; Naregal, Language, Politics, Elites, p. 5 .

11 Bate, 'The Ethics of Textuality', p. 102.

12 The desire for a written standard is not unique for Telugu. For instance, in the Hindi case, Orsini argues, 'Where earlier several linguistic repertoires existed, one standard was now being developed to comprise spoken and written, mundane, literary, and religious usages in an unbroken continuum'. Orsini, The Hindi Public Sphere, p. 23.

${ }^{13}$ Gidugu Venkata Ramamurti (1986), Sora-English Dictionary. New Delhi: Mittal Publications. The Sora language has interestingly become the subject of a notable 
Telugu language and literature (he began a journal in the 1930 s called Pratibha ${ }^{14}$ dedicated to these concerns), Ramamurti became the spokesperson for a new Telugu that would be able to traverse the boundaries of modern genres of writing that flourished in the colonial era-such as newspapers, essays, histories, novels, short stories, and poetry. A democratic impulse prompted Ramamurti to declare that there should only be one Telugu that was accessible to everyone alike, from poet to peasant. Ramamurti wanted to remove the diglossia, the co-existence of a formal language alongside a colloquial form, present in Telugu and replace it with a unified Telugu that was more pliable and suited to a modern democratic culture.

\section{Language, progress and historical change}

In the last decades of the nineteenth century, in the Madras Presidency, a number of prominent Telugu writers began to express concern with the progress and development of the Telugu language and literature. A pioneer in modern literature and social reform activities in Andhra, Kandukuri Veeresalingam (1848-1919) began to self-consciously reflect on improving the Telugu language. Essays on the progress of the Telugu language began to appear more frequently in the 1890 s and by the early years of the twentieth century the influential literary journal Andhra Sahitya Parishad Patrika began to publish historical and literary essays on Telugu. ${ }^{15}$ The particular concern with the future of Telugu constitutes a break from previous colonial engagements with the language. Telugu had been the subject of colonial scrutiny throughout the nineteenth century with the establishment of the Fort Saint George College in Madras in $1812 .{ }^{16}$ There were Indian pandits (traditional scholars) as well

documentary called 'The Linguists' (Ironbound Films, 2009) on the extinction of languages and the loss of knowledge-systems in the process.

${ }_{14}$ First issue was published in May 1936. It was called the Journal of the Association for New Literature.

${ }^{15}$ See K. R. V. Krishna Rao (1896), Andhra Bhasa Abhivrddhi [The Progress of Telugu Literature]. Rajamundry: Vivekavarthani Press, and P. Gopal Rao Naidu (1986). Andhra Bhasa Charitra Sangrahamu [Summary of the History of the Andhra Language]. Rajamundry: Vivekavarthani Press. See vols. 1-2 of Andhra Sahitya Parishad Patrika (1912-1913).

${ }^{16}$ See Rama Mantena (2005). 'Vernacular Futures: Colonial Philology and the Idea of History in Nineteenth-Century South India', Indian Economic and Social History Review 42:4. 
as colonial scholars who studied Telugu. The latter wrote grammars and dictionaries, whereas the former experimented with new prose styles such as the essay, short stories and the novel in Telugu. However, the concern with the progress of Telugu signalled a turning point. It is worth pondering how the progress of a language and the progress of a people were almost entirely conflated in this period. In particular, consider the questions that were in circulation at the time: how Telugu fared in relation to other Indian languages and in relation to European languages; or, was Telugu on a path of improvement or was it in decline? The progress of the language was expected to mirror the social changes underway in colonial society-changes sought by social reformists and their agenda of the uplifting of the underclass, including women. In this section, I will first examine the general discussion surrounding language and regionalism-an emerging consciousness of the region as socially and politically distinct. Then I will turn to the discourse of social reform that informed the representation of the future of Telugu and future of the Telugu-speaking people as necessarily intertwined.

In 19o6, an association devoted to the progress of Telugu language and literature was established called Vignana Chandrika Mandali by A. Kaleswara Rao. Rao wrote that the association was formed

(a) to create a healthy prose literature in Telugu chiefly consisting of books on History, Biography, Science and Romance and translation of important English works such as Smile's Character, Blackie's Self-culture, Lubbock's Pleasures of Life, (b) to encourage the study of western science and culture through vernaculars by instituting examinations, prizes and medals'. ${ }^{17}$

The association was to promote literary ventures in science and other new genres in Telugu in order to foster a healthy publicly turned prose (rather than the narrowly focused prose and poetry of literary Telugu). The association was also explicitly concerned with publishing translations of books of English prose into Telugu. The Mandali under the name of the Vignana Chandrika Parishad began to conduct examinations in Telugu starting from 1912. At the turn of the twentieth century, there was a surge of activity in literary production and urgent calls for improving the state of Telugu literature. Modern literary criticism was borne out of this efflorescence

${ }^{17}$ Rao, K. V. N. (1973). The Emergence of Andhra Pradesh. Bombay: Popular Prakashan, p. 15 . 
in Telugu literary production. ${ }^{18}$ Between the 1870 s and 1900 , it is estimated that around $5^{0}$ to 60 novels were written in Telugu. In 1892, the monthly periodical, Cintamani, was started by Nyapati Subbarao, one of the leaders of the Andhra Movement who presided over the second Andhra Conference held in the city of Vijayawada in $1914 \cdot{ }^{19}$ Subsequently, K. Veeresalingam, Acanta Sundararamayya and Vavilala Vasudevasastri jointly ran Cintamani. In order to provide institutional encouragement for the production and sustenance of the Telugu novel, Cintamani sponsored a prize for novels in 1893 . The journal sponsored debates over the merits of the novel as a new genre in Telugu over existing genres. In another influential journal, Rajayogi, in the 1890 , Kasibhatta Brahmayya Sastri wrote an essay on Viresalingam's Rajasekharacharitra and referred to it as a novel. ${ }^{20}$ The Vignana Chandrika Mandali also held competitions for historical novels and encouraged the writing of histories on Andhra. ${ }^{21}$ In 1932, Andhra Visvakala Parishad announced another competition to which were submitted Adivi Bapiraju's Narayana Rao, Visvanatha's Veyi Padagalu, and Chalam's Maidanam - three literary giants of Modern Telugu. ${ }^{22}$ The journals and their literary competitions created the conditions for creative outpourings from writers who were encouraged by the expansive Telugu literary public. The promotion of new literary forms and the new media that widened dissemination of those forms gave a larger number of Telugu-speakers access to written Telugu. This inevitably allowed a wider community to take charge of the

${ }^{18}$ Kasibhatta Brahmayya Sastri, a literary critic who wrote influential essays on Telugu literature in 1896 , came up with a term for criticism in Telugu, 'vivekacandrika vimarsnam' [criticism]. See Akkiraju Ramapatirao (1983), 'Telugulo parishodhananavala-chinakatha' in Devulapalli Ramanujarao, PSR Apparao, G.V. Subrahmanyam, Iriventi Krishnamurti, eds, Telugulo Parishodhana. Hyderabad: Andhra Pradesh Sahitya Akademi, pp. 197-198.

${ }^{19}$ Nyapati Subbarao was also one of the founders of The Hindu newspaper in Madras. He was an active member of the Indian National Congress. He became friend and admirer of Swami Vivekananda when the latter returned from the World Religions Conference in Chicago. In 1897 , Subbarao was part of the welcoming reception in Madras for Vivekananda and he continued his friendship with him. As a tribute to his great admiration of Vivekananda, Subbarao founded the Hindu Samajam in 1905 in Rajahmundry.

${ }^{20}$ Akkiraju Ramapatirao, 'Telugulo parishodhana-navala-chinakatha', pp. 197198.

${ }^{21}$ Writers such as Gurjada Sreeramamurthi (Kavi Jivitamulu, 1878), K. V. Lakshmana Rao and Chilukuri Veerabhadra Rao (Andhrula Charitra, 1910) wrote histories.

${ }^{22}$ Akkiraju Ramapatirao, 'Telugulo parishodhana-navala-chinakatha', p. 199. 
written language and to make use of it in multiple contexts. This is a marked turn away from the once rarified existence of literary Telugu. The advent of print ushered in new written forms of Telugu and widened the pool of new audiences.

In 1914, Nyapati Subbarao at the second Andhra Conference declared, 'There is an awakening among the Andhras and a renaissance in Telugu Literature comparable to the days of Krishnadevaraya, less dependent on the favour of princes and more firmly based on the appreciation of the people'. ${ }^{23}$ Due to his own persistent efforts and the efforts of his contemporaries, Nyapati Subbarao contributed to the so-called renaissance, he witnessed during his own lifetime, of Telugu language and literature. In his speech he also alluded to the work of his contemporaries in cities such as Madras (the Vignana-chandrika series), in Nidadavole (the Andhra Pracharini Grandha Nilayam) and in Masulipatam (the Andhrabhasabhivarthani Sangham). He points to the enrichment of Telugu with the advent of scientific and fictional literature. Most importantly as he ended the above quote that this renaissance is based 'on the appreciation of the people' because through the advent of and wide dissemination of print media, it became possible to bring out 'cheap and useful literature within the reach of the masses'. ${ }^{24}$ With a wider Telugu-reading public awakened by the proliferation of print media and the cultivation of and dissemination of new literary forms, it becomes starkly clear that literary Telugu is not just the property of elite/isolated literary communities. Nyapati was attuned to the reshaping of Telugu literary taste that accompanied the prevalence and circulation of print media.

This was a remarkable preoccupation with 'Andhra Bhasa' or the language of Andhra in the writings of Telugu intellectuals. Institutional fostering of these sentiments were sustained through the establishment of another important association, the Andhra Sahitya Parishad in 1911 alongside its first news journal printed in 1912. The Parishad was under the patronage of the Maharajah of Venkatagiri and the Rajah of Pithapur, and undertook the Herculean task of publishing a comprehensive dictionary with the guidance of the preeminent Telugu scholar, Jayanti Ramayya. Through the support of the Parishad, Ramayya began to publish his numerous findings on Andhra history. As a skilled epigraphist, Ramayya sought to reconstruct the

${ }^{23}$ G. V. Subba Rao (1982), History of the Andhra Movement (Andhra Region): Volume 1. Hyderabad, p. 239.

${ }^{24}$ Ibid. 
history of the Andhra region through interpretations of early modern temple inscriptions. He also wrote extensively on the Telugu language and often represented it as a mother tongue (matrubhasa). ${ }^{25}$ The emergence of associations organized around Telugu language and literature contributed to the rising sentiment in valorizing language. There have been some remarkable studies on the development of this new consciousness around one's attachment to one's mothertongue and love of language, especially in southern India-most prominent of course is Sumathi Ramaswamy's research on Tamil and more recently Lisa Mitchell's work on Telugu. ${ }^{26}$ Both Ramaswamy and Mitchell consider the passions stirred by the new cultivated love of language that fuelled linguistic nationalism in the twentieth century. Linguistic nationalisms were successful in that they were able to push for a reconsideration of provinces within India along linguistic lines. However, we should be cautious not to uncritically contribute to the teleology of linguistic nationalism by supplying a historical narrative for its emergence as if it were inevitable. Regional consciousness seemed to align easily with the goals of linguistic nationalism in pushing for linguistic boundaries as the natural boundaries of provinces. The precariousness of nationalisms is such, however, that we should be wary of their self-proclaimed loyalties to language. For instance, in contemporary Andhra Pradesh there seems to be a breakdown of consensus on the question of language and nationalism with the recent political challenge launched by Telangana activists. In a recent Economic and Political Weekly article, historian Yamada Keiko argues that in fact linguistic nationalism in Andhra Pradesh has to be seen as a failure as we see the new uprisings in Telangana opening up old grievances. ${ }^{27}$ Yet it would be foolish to dismiss the power of the discourse surrounding the love of language at the beginning of the twentieth century, even if it is within the volatile contexts of ever-shifting desires and goals of nationalism and its claims to territory.

${ }^{25}$ See Mitchell, Lisa (2009). Language, Emotion, and Politics in South India: The Making of a Mother Tongue. Bloomington: Indiana University Press.

${ }^{26}$ See Sumathi Ramaswamy (1997), Passions of the Tongue: Language Devotion in Tamil India, I89I-1970. Berkeley: University of California Press and Mitchell, Language, Emotion, and Politics.

${ }^{27}$ Yamada Keiko (2010), 'Origin and Historical Evolution of Modern Telugus', Economic and Political Weekly, Vol. XLV No. 34, pp. 57-63. 


\section{The Andhra Movement and the social agenda}

'Why are the Telugus a Backward People Now?', asked The Hindu on 17 August 1911. The concern was not only with the development of Telugu alone, as already suggested, but also with its intimate counterpart and presumed twin, the progress of the people at large. J. Gurunatham, a member of the Young Men's Literary Association, ${ }^{28}$ was writing articles to provoke Telugu speakers to think of their own 'backwardness'. J. Gurunatham and U. Lakshminarayana prepared a map of Andhradesa showing the Telugu-speaking regions in the Madras Presidency, the Central Provinces, the Nizam dominions and Mysore state. They began to discuss the regrouping of Teluguspeaking provinces as a way to make a claim for the distinctiveness of the political needs of the Telugus. In 1913, one of the prominent leaders of the Andhra Movement, Konda Venkatappayya, along with J. Gurunatham, published a tract, For and Against Andhra Province. Venkatappayya described these initial discussions between J. Gurunatham, U. Lakshminarayana and Challa Seshagiri Rao as 'emotional and ambitious'. He went on to say that he suggested to the group that rather than demand an immediate separation of the Telugu-speaking regions into one province that it might be more tactful to

start an Andhra Maha Sabha, hold annual conferences to discuss ways and means to improve the physical, economic and moral conditions of Andhras, and to bring about the all-round development, unity and awakening among the Andhras and for these purposes we should carry on propaganda' ${ }^{29}$

The emphasis was placed on the improvement of 'the physical, economic and moral conditions of Andhras'. In his 1938 tract The Andhra Movement, Venkatappayya wrote 'The Andhra movement is only an attempt to open their [the Telugu people's] minds to their present backwardness and induce individual exertion as well as corporate action on their part to improve their condition' ${ }^{30}$ The

${ }^{28}$ Established in 1903-1904 in Guntur.

${ }^{29}$ K. V. N. Rao, The Emergence of Andhra Pradesh, p. 35. Quoted from Konda Venkatappayya's Sveeyacharitra [Autobiography].

${ }^{30}$ K. Venkatappayya (1938), The Andhra Movement. Andhra Maha Sabha, pp. 9-10. 
Andhra Conference Committee in 1913 accepted the following goals outlined by Venkatappayya:

1) Creating among the people great love for education, culture and high ideals and making provision for their special educational needs by representation to the Government and by other means;

2) Studying the agricultural and commercial conditions of the country and concerting measures for their progress by creating a spirit of co-operation and by developing mutual trust and confidence;

3) Stimulating interest in sanitation, health and physical culture and suggesting the means of promoting the physique of the present generation;

4) Promoting the development of Telugu literature by encouraging the publication of books in the vernacular which are intended to convey the principles of modern culture and enlightenment to the masses;

5) Securing the advancement of the claims of the Telugus in public service. ${ }^{31}$

This was remarkable concern for the progress of Telugu society. Concern with the current state of Telugu language and literature and its future as discussed by the earlier group of cultural associations, such as the Vignana Chandrika Mandali and the Andhra Sahitya Parishad, gave way to broader discussions on the general health of the Telugu-speaking population. Nyapati Subbarao, at the second Andhra Conference held in Vijayawada, insisted the two concerns were intertwined (the state of the Telugu language and the people) that although the Andhra movement had wider concerns

it is felt a common language and literature is [a] sufficiently strong tie to weld people together, and appealing to their past glory, it awakens them to their present state of backwardness, so that they might work together in a spirit of self-sacrifice for the uplifting of themselves, ${ }^{32}$

Nyapati Subbarao was indeed expressing a progressive agenda that had the imprint of a social reformist agenda. Interestingly Nyapati

31 Ibid., pp. 9-10.

${ }^{32}$ G. V. Subba Rao, History of the Andhra Movement, p. 239. The Andhradesa Libraries Conference was held in 1914 and within five years of its meeting the number of libraries in the Andhra region increased from 163 to 486. The Library Movement under the Presidency of Nyapati Subbarao stated its goals as the desire for a national system of education, universal literacy, female education and even homes for widows. 
was not asking the Telugu people to harness the concern with past traditions of a common literature and language towards nationalistic or regionalist sentiments, rather, it seems the search for common past traditions was to 'weld people together' towards a different set of goals: to arise from a state of social and cultural 'backwardness' and to uplift themselves. The interest in the health of the population was expressed in terms of sanitation and the care of the physical body of the new citizen. The promotion of Telugu literature and its dissemination to a broader Telugu public would indeed cultivate and advance the social and political goals of the people.

\section{Gidugu versus Ramamurti and spoken Telugu}

Yet another movement emerged which focused on the Telugu language and was concerned rather exclusively with widening the scope of the Telugu public sphere in order to encourage the democratization of the Telugu language-expanding the readership of Telugu written traditions. This involved parallel and often overlapping discourses surrounding Telugu as a language. However, whilst cultural historians and anthropologists of India have given attention to understanding the linking of language to nationalism and regional consciousness, the goal of democratizing language has not been given its share of historical scrutiny. In this section, I explore what were the conditions of emergence of this particular set of concerns surrounding the democratization of Telugu. Two of the most prolific writers committed to educational reforms in the coastal regions of Andhra were Gurjada Appa Rao and Gidugu Ramamurti who spearheaded the movement to reform Telugu, particularly to make written Telugu reflect the spoken forms of the day. What was fascinating about Ramamurti's and Appa Rao's concerns with language was not so much the affective loyalties to language that a particular linguistic community harbours, rather it was their primary concern with prying apart what they perceived to be the traditional elite and their hold on language. This would have profound implications for literary innovation during this period. They both argued that what the defenders of classical Telugu were advocating was an invented or artificial Telugu that kept large numbers of Telugu-speakers alienated from their own history (from the movement of history) and literature because the written tradition was kept distant from the masses with its high literary style of prose. It is this aspect of the politics 
of language that has received little attention-often being swept under the framework of linguistic nationalism. Ramamurti's views of language suggest the necessity of a unified Telugu (something that linguistic nationalism also invested in) that should become the medium of new communicative practices for the emergent public sphere. The thrust of his argument lay in asking Telugu intellectuals and writers to turn their gaze away from the teaching of classical literature to identifying what forms of spoken Telugu were current and using these as a basis for teaching Telugu grammar and composition in schools and colleges.

At first glance, when looking at the writings of Ramamurti, it is all too easy to dismiss him as a blind enthusiast of Western modernity in his excitement over the possibilities of the radical transformation of traditional Indian society. His embracing of modern technology and forms of communication-as ushering in new social relations and having the potential to eliminate existing social inequities-was the inverse of Gandhian views of the modern. Gandhi was hesitant to concede that modern technological innovations possessed the potential to free and loosen societal inequities. ${ }^{33}$ In fact, Ramamurti's view of modernity was without the ambivalences that plagued many nationalists, most noteworthy was of course Gandhi who embraced an explicitly anti-modern stance. However, Ramamurti did share similar goals with other nineteenth-century social reformers. He writes:

I am only urging the necessity and duty of reversing the unnatural obstacles that impede the progress of the masses. The aim of the true social reformer in all civilized countries is to weld all classes of the community together for common citizenship. ${ }^{34}$

However, it is worth noting that Ramamurti's vision of a new society is not simply one of a modern rationally ordered society but rather one ordered and upheld by democratic institutions. And this, I believe, distinguishes him from the social reformer of the nineteenth century who concerned himself with the eradication of social ills because of his adoration of 'reason' and rationality as a principle organizing social life. Ramamurti did not simply view the peasant or lower castes as solely objects of reform for the greater good of society and he did not have revulsion towards superstition and so-called 'backward' elements

${ }^{33}$ M. K. Gandhi most famously argues this in Hind Swaraj. See Anthony Parel (2009), ed., Gandhi: 'Hind Swaraj' and Other Writings. Cambridge: Cambridge University Press.

${ }^{34}$ Gidugu Venkata Ramamurti (1913), A Memorandum on Modern Telugu. Madras, p. 21. 
in society as some nineteenth-century social reformers. Ramamurti certainly cultivated a strain of Romantic nationalism especially his view of natural language that bound a society together despite social hierarchies. However, he formulated a critique of what he saw as an 'invented' tradition of sorts - the use of 'classical' language as a written standard. His envisioning of a popular language was part of his broader commitment to liberal democratic culture.

Ramamurti was born in 1863 in the village of Parvataalapeta in the district of Srikakulam, in present-day Andhra Pradesh. The region was part of the Northern Sarkars tracts that frequently changed hands in the eighteenth century between the French and the English and ultimately became incorporated in the Madras Presidency. Before Ramamurti was born, his father, Viraraju, had settled in Vijayanagaram when he took up work in a revenue inspector's office between 1860 and 1875 . Viraraju died when Ramamurti was only 12 years old but the family continued to reside in Vijayanagaram. Ramamurti went to school in the Maharaja's school (this was also where Gurjada Appa Rao attended school) in Vijayanagaram and learnt English there. Ramamurti could not continue his studies after graduation because of financial constraints, whereas Gurjada went off to college. Ramamurti's first job was in a Collector's office in Visakhapatnam. He was disappointed with that job and decided to move to Parlakimidi (in present-day Orissa). He taught for 30 years in Parlakimidi, and it was here that he immersed himself in expanding his knowledge of educational theories and the new field of linguistics as it applied to the teaching of language. While in Parlakimidi, Ramamurti established an association called 'Reading Room' which sponsored various talks on social reform and politics. One such talk was by $\mathrm{R}$. Venkataratnam Nayudu on the influential social reform association from Bengal, the Brahmo Samaj in $1895 .{ }^{35}$

At this time, Ramamurti also came into contact with a prominent British educator in India, J. A. Yates, a civil servant who was principal of Pachhaiyappa College (Madras) in $1906 .{ }^{36}$ Yates commented on

${ }^{35}$ Gidugu Sitapati, 'Gidugu Venkataramamurti Pantulu (Jivita Charitra: Varu Rachinchina Grandhamulu) [Pantulu Gidugu Ramamurti: His life story and the books written by him]', Sahityopanyaasamulu: Svagriya Gidugu Ramamurti Pantulu [Speeches on Literature: Pantulu Gidugu Ramamurti]. Hyderabad: Andhra Pradesh Sahitya Akademi, p. 8.

${ }^{36}$ In 1839 , Pachaiyappa Charities was incorporated as a permanent and selfperpetuating trust to be used solely for Indian education. Pachaiyappa School was founded in Madras in 1843 , which gained the status of a college in 1889 . 
what he saw as the slow progress of Telugu teaching in classrooms in Visakhapatnam and decided to seek out answers as to why this was so. Yates met with Gurjada Appa Rao and then proceeded to seek a meeting with Ramamurti whom he had heard about, especially his critical views of how Telugu was ineffectively taught at primary level. ${ }^{37}$ Yates and Ramamurti maintained their friendship and in 1934 Yates expressed his strong admiration for Ramamurti. Yates wrote, 'I think apart from the logic of his appeal, it was the call to liberty in it and the humanity of it, since it meant freedom to the poor and the outcast, that took me from the beginning. ${ }^{38}$ Yates supported the work of both Gurjada Appa Rao and Gidugu Ramamurti in promoting the 'Spoken Language' movement. Both Gurjada Appa Rao and Ramamurti as advocates of the spoken language movement believed that new educational theories and insights gained from linguistics should be taken into account in reforming the teaching of Telugu in schools. The emphasis on spoken language was the idea that teaching Telugu grammar and composition can only be effective in schools if teachers acknowledge the necessity of teaching children their own mother tongue. Ramamurti relied on Philip J. Hartog's The Writing of English (1907) to formulate methods of teaching Telugu school children.

At the time that Ramamurti met Yates, he was a history lecturer at Parlakimidi College. He also began to give speeches on language. For instance, in 1908 in Visakhapatnam, Ramamurti gave a talk on 'Bhasa Charitra-Telugubhasha Charitra [The story of languagethe story of Telugu]'. He retired from the College at Parlakimidi in 1911 and became increasingly involved in debates over language use in educational institutions. In 1912 the University of Madras sponsored a talk by the British linguist Daniel Jones on the subject of phonetics. Jones was a pioneer in Britain in the field of modern Phonetics and a proponent of Spoken English. ${ }^{39}$ Both Ramamurti and his son

${ }^{37}$ Gidugu Sitapati, 'Gidugu Venkataramamurti Pantulu (Jivita Charitra: Varu Rachinchina Grandhamulu) [Pantulu Gidugu Ramamurti: His life story and the books written by him]', p. 16.

${ }^{38}$ Telikicharla Venkataratnam (1964), 'Adhunikandhra Sahityampai Gidugu Ramamurtipantulugari Prabhavamu [The Power of Gidugu Venkata Ramamurti in Modern Literature]'Sahityopanyaasamulu: Svagriya Gidugu Ramamurti Pantulu [Speeches on Literature: Pantulu Gidugu Ramamurti]. Hyderabad: Andhra Pradesh Sahitya Akademi, pp. $45^{-4} 6$.

${ }^{39}$ Daniel Jones (1881-1967) was appointed Lecturer in Phonetics at University College, London, in 1907. He served on the BBC Advisory Council on Spoken English and served as president of the International Phonetics Association. 
Sitapati attended the talk which seemed to make a deep impression on both of them. Ramamurti and Sitapati were asked to tutor the son of the Vijayanagaram Maharajah (king) in 1912-a job Ramamurti readily accepted. In 1912 , Ramamurti became part of an influential committee called the Composition Committee at the University of Madras, which included Gurajada Appa Rao, Gidugu Ramamurti, P. T. Srinivas Iyengar, and Burra Seshagiri. ${ }^{40}$ The Committee members attended the fourth anniversary meeting of the Andhra Sahitya Parishad in Kakinada. Whilst there they stayed at the estate of the Polavarm zamindar.

In 1913, fearing that the Government of Madras would allow the teaching of Telugu in schools and universities to carry on as it had throughout the nineteenth century, Ramamurti sent a memorandum on modern Telugu to the governor of Madras to propose new reforms. In the memorandum he argued for radically re-structuring the teaching of Telugu in schools and laid out a broad critique of how Telugu had been ineffectively taught by a class of Telugu pandits (traditional scholars) who were not versed in new educational theories that privileged the linguistic repertoires and experiences of the child first. On the whole, Ramamurti viewed British educational efforts in India positively as having created the conditions for producing a large literate class and for closing the gap between classes. He saw modern schooling as a truly democratic force in the education of people towards the goal of equalizing the classes.

\section{A new prose}

In his now famous memorandum, Ramamurti contended that something un-natural occurred with respect to Telugu in the nineteenth century. He argued that Pandits, traditional scholars, who were employed by the colonial state in educational institutions, attempted to introduce an antiquated form of literary language for language instruction in schools. He suggested that,

attempts to write Prose began to be made sometime after the British Government had established the new system of Public Instruction and some progress had been made in the education of the people. But unfortunately Telugu Prose like Telugu Poetry has fallen into the hands of the pedantic

${ }^{40}$ Gidugu Sitapati, 'Gidugu Venkataramamurti Pantulu (Jivita Charitra: Varu Rachinchina Grandhamulu) [Pantulu Gidugu Ramamurti: His life story and the books written by him]', p. 28. 
Pandit whose ideal it seems to have been to write as unintelligibly as possible'. ${ }^{41}$

Whereas many literary historians would contest Ramamurti's attributing the emergence of Telugu prose to the advent of British rule in India, it is clear that he was more concerned to demonstrate not the historical origins of prose but rather that the evolution of Telugu prose came to stagnate through the retrogressive efforts of the 'pedantic pandits'. Ramamurti even singles out social reformer, Kandukuri Veeresalingam, a pioneer in modern Telugu literature, as having unconsciously reproduced some of these antiquated forms of Telugu grammar, which Ramamurti considered 'fetters' that prevented the development of free expression in Telugu. The figure of the pandit occupied a curious place in Ramamurti's essays as someone who was accidentally thrown into the business of reforming language when he was genuinely not interested in reform perhaps because of his past loyalities (patronized at the courts of pre-colonial kingdoms). ${ }^{42}$ Telugu pandits had entered colonial service since the founding of the Fort St George College in Madras in 1812 . Pandits were recruited by colonial institutions for the teaching of vernaculars such as Telugu, initially for the training of junior civil servants. They were seen as an obvious choice for these new positions since they were the traditional literate class. However, their conception of grammar differed fundamentally from what the Europeans were expecting. Literary historian Velcheru Narayana Rao argues, 'the purpose of grammar, in their worldview, was not to teach the language but to generate the language legitimised for literary use'. ${ }^{43}$ Pre-colonial conceptions of grammar that the pandits held led them to produce particular kinds of grammars and language instruction tools in colonial institutions. First,

${ }^{41}$ Gidugu Venkata Ramamurti, Memorandum on Modern Telugu, p. 2.

42 Ramamurti in an Appendix to the Memorandum on Modern Telugu writes, 'I have used the word 'Pandit' in this pamphlet to mean pedantry, bigotry, dogmaticism, unreasonableness, impracticable purism, exclusive spirit and such other characteristics of the average Pandit' (p. 59). However he claims he does not want to slander particular Telugu pandits because he has the greatest respect for the Pandit's scholarship and his love of knowledge and devotion to study.

${ }^{43}$ Velcheru Narayana Rao (2004), 'Print and Prose: Pundits, Karanams, and the East India Company in the Making of Modern Telugu', in Stuart Blackburn and Vasudha Dalmia, India's Literary History: Essays on the Nineteenth Century. New Delhi: Permanent Black, p. 153. See Mitchell, Language, Emotion, and Politics. Mitchell argues that, 'the explicit goal of 'learning language' was rarely the aim of formal or informal education' (p. 1 29). She suggests that in the new orientation of learning language in educational institutions, language became an object, an end in itself. 
grammars and textbooks were produced for the training of junior civil servants and later for native schooling. Ramamurti suggests that this nineteenth-century tradition of relying on pandit efforts produced inadequate language instruction tools for modern schooling.

Whereas Ramamurti certainly believed that nineteenth-century pandits possessed a very different conception of grammar which worked to alienate a literary language from a large number of its users, it is important to consider that Ramamurti himself began to articulate a very different conception of grammar and language. His study of modern linguistics and exposure, especially to the emergent field of modern phonetics and the practical proposals for spoken language within the field, provided Ramamurti with new ways of conceptualizing language in relation to society. He believed the child should come first in educational endeavours. First, teachers should be able to recognize and develop children's powers of observation and ability to learn through their initial language experiences, suggesting that a child's vernacular speech results from the training of an instinctive function within children and that it is an integral part of their mind and body. ${ }^{44}$ Any educational policy must acknowledge these fundamentals of early childhood development.

Ramamurti contends that the changes he proposes in the teaching of Telugu have historical parallels in Europe. He writes that,

English itself was long treated with scorn by the bigoted 'Pandits' of the English Universities; but for the continued efforts of patriotic men, possessed of little Latin and less Greek, English would not have attained to its present stage. In the second place the modern writer claims his right to modernize the contents as well as the language of literature and extend its scope so as to embrace all the phenomena of social life as it now is. The roots of the Pandit's literature are in the remote past and its conventions are based on a social life which has now changed to a great extent. The Pandit cannot realize that the literature of a nation, if it is really national, reflects the life of a nation. ${ }^{45}$

Ramamurti alludes to the prominent place of classical education in nineteenth-century England. ${ }^{46}$ The idea that even in England the representatives of a literary elite upheld the study of Greek and Latin that formed a classical education as culturally and pedagogically important over and above the study of English. Ramamurti is clearly

${ }^{44}$ Gidugu Venkata Ramamurti, Memorandum on Modern Telugu, p. 15.

${ }^{45}$ Gidugu Venkata Ramamurti, Memorandum on Modern Telugu, p. 27.

${ }^{46}$ As Gauri Viswanathan and others have shown that English as a subject of study in universities emerged in that century. See Gauri Viswanathan, Masks of Conquest. 
drawing on the idea of the mother tongue as providing a natural link between the individual and society. He suggests an analogous relationship between the role of classical education in England and the role of Sanskrit and classical Telugu in nineteenth-century Andhra. The study of classical literatures - though they have their uses-are structured to make literary cultures inaccessible to larger publics. $\mathrm{He}$ argued that the curriculum of classical literatures was essentially antidemocratic. However, he believed the study of the mother tongue and the language of everyday interaction could potentially broaden the Telugu public sphere.

In the nineteenth century, three historical forces can be identified that impacted language study in south India: missionary efforts, colonial efforts, and the 'pandit' efforts. ${ }^{47}$ Missionary efforts were critical in the interests of producing language instruction materials (grammars and dictionaries) and thereby contributing to the spread of print technology in colonial India. Early colonial efforts in language study, especially those epitomized in the work of nineteenth-century philologist C. P. Brown for Telugu, turned to the Telugu prose circulating in administrative use. Brown, a colonial civil servant, endeavoured to produce a modern grammar and dictionaries for Telugu essentially documenting that prose. Brown also employed many Telugu scholars who were given the task of compiling versions of Telugu literary classics, often rewritten in Telugu prose. However, when it became time for hiring Telugu teachers in colonial educational institutions some, like the Fort St George College, turned to traditional pandits who proposed the dissemination of a very different kind of Telugu prose-an educated prose (literary prose that was dictated by prescriptive grammar-in the tradition of yyakarana [the science of grammar]). Was this due to the pandit's very different conception of grammar and its relationship to language and literary production? It seems this is very likely the case rather than some antiquated response to the march of modernity and progress through modern schooling efforts.

If pre-colonial Telugu was bifurcated between literary language and administrative language (or non-literary language), then what happened when the path of literary prose (metrical prose) and the path of administrative prose collided in the nineteenth century? Was it the homogenizing and standardizing forces of modern education

${ }^{47}$ See Velcheru Narayana Rao, 'Print and Prose'. 
that called for the convergence of these separate trajectories? Modern instruction in language dictated that literary and non-literary prose should rely on a similarly agreed-upon set of grammatical principles. The set of changes brought about with the advent of print and modern schooling are undoubtedly central to the crafting of a new unified prose in the colonial era.

In the Telugu case, readers and writers were not waiting to hear the verdict on how best to write their prose. With the proliferation of print media, of literary and public associations and textbook societies in the later half of the nineteenth century and the early decades of the twentieth, a Telugu public sphere emerged parallel to what others have documented for Hindi, Marathi, Bengali, and Tamil. ${ }^{48}$ The conceptualization of a Telugu public sphere gives a historical framework in order to understand the broader changes concerning language use, literary practice, and the proliferation of print mediaall of which clearly shaped modern Telugu prose that proliferated in the twentieth century. For instance, while Gidugu Ramamurti and Jayanti Ramayya were debating on the best prose appropriate for modern literary use, clearly prose was already proliferating in multiple arenas. Telugu journals appeared starting in the 1830 s (Vrittantini published in Madras in 1838) dedicated to the explicit dissemination of social reform ideas. Judging from the proliferation of Telugu newspapers and journals in the latter half of the nineteenth century we can speculate that the reading public had increased considerably from the early colonial period when the concerns seem to have been with creating institutions to foster vernacular publics. The dominance of social reform as a topic of concern shows the inwardturn to society sustaining the production of this literature. Swamineni Muddunarasimhan experimented with the essay as a form of social and political commentary most thoroughly in Telugu in his collection of essays entitled Hitasucini published in $\mathbf{1 8 6 2}$. The prose style in Hitasucini was new and it tackled different social issues of the day from the education of girls to science and technological improvements in modern life. And the dominance of Kandukuri Veeresalingam's literary career in the latter half of the nineteenth century gave impetus to the cultivation of a new Telugu prose. Veeresalingam started two Telugu journals in 1876 , Vivekavardhani and Hasya Sanjivini; in 1885 he began two more journals focussing on women's issues, Satihita Bodhini

${ }^{48}$ Naregal, Language, Politics, Elites; Orsini, The Hindi Public Sphere; Bate, Tamil Oratory. 
and Sandhi Tantra. In Vivekavardhani he promoted the idea that people should write primarily in prose (in the vernaculars) on all modern topics. In his autobiography Veeresalingam took pride in his many accomplishments as he proclaimed: 'I penned the first prose work in Telugu; I was the first to render drama in Telugu; the first Telugu book on natural sciences and on history were authored by me. I was the first to write books in prose for women'. ${ }^{49}$ When Gurjada Appa Rao and Gidugu Venkata Ramamurti began to propose the 'modernizing' of Telugu prose in the early decades of the twentieth century, prose in Telugu was already flourishing in multiple publics. Yet the spoken language movement for Telugu proposed that a specific Telugu had to be cultivated-the spoken forms. Ultimately it was a critique of literary Telugu and the exclusive literary community it implied.

\section{Modern schooling}

In order to dismantle the exclusivities cultivated by classical literary Telugu and the literary communities that sustained it, Ramamurti stressed the overhauling of traditional educational methods in primary schools. An important pedagogical principle that Ramamurti elaborated in his memorandum on Modern Telugu was to discourage the exclusive reliance on memory and to develop a capacity to reason in the pupil. This was a familiar charge made against traditional Indian education-rote learning did not allow the growth of the capacity to reason. Ramamurti passionately advocated object lessons in primary education in India as a way to cultivate critical thinking in the pupil. He also believed it was natural to develop a child's sense of language from what he knew from experience-the everyday use of his mother tongue. Ramamurti argued that,

modern Indian teachers want the Reading books to be written in the language familiar to children, and the children to be taught few words along with new ideas only in relation to things, by means of conversational lessons, before they are allowed to read these words in books, so that they may early be habituated to the feeling that words represent real ideas and things. ${ }^{50}$

In the memorandum, Ramamurti extensively discusses the British colonial government's critique of traditional Indian methods of

${ }^{49}$ Quoted in K. V. N. Rao, The Emergence of Andhra Pradesh, p. 9.

${ }^{50}$ Gidugu Venkata Ramamurti, Memorandum on Modern Telugu, p. 19. 
pedagogy that rely on memory and their insistence on the introduction of object lessons to improve indigenous systems of learning. Parna Sengupta's study of colonial pedagogy reveals the centrality of the object lesson in colonial schooling. ${ }^{51}$ She contends that,

Metropolitan and colonial primary school teachers felt that the primary focus of object lessons was to educate children in one of the fundamental tenets of 'modern' Western theory: the subordination of the object to the subject. Yet this was meant to be done almost counter-intuitively, using concrete objects (or pictures of object) to help children think abstractly. ${ }^{52}$

Though originally adapted and employed by the Evangelicals in England and brought to colonial India, object lessons in the nineteenth century were promoted for the primary school student to develop scientific thinking and experimentation. Sengupta writes that this approach to primary education was thought to be most appropriate for lower class children to be taught through a concrete and empirical relationship to the world. It was precisely this move away from classical literary education, meant for the elite few to education encompassing the lower classes, that Ramamurti was enamoured by. He too developed a critique of classical literary training and its inadequacies in preparing the pupil with democratic sensibilities working towards a common citizenship. Ramamurti showed immense frustration with the intransigence of Telugu pandits in shifting from their pedagogical goals of classical literary training which, he believed, was a hindrance to gaining competency and fluency in Telugu reading and composition.

In an essay entitled 'People's literature' or 'Prajaa saahityam', Ramamurti argues that a new society is emerging in India-a movement towards greater equality between classes and a movement towards self-rule. He writes that,

the momentum of the world is dependent these days on the universities and voluntary associations. The Telugu people, with brotherly commitment to

${ }^{51}$ Johann Pestalozzi (1746-1827) was inspired after reading Rousseau's Emile as well as drawing inspiration from the philosophical empiricism of Locke and Hume. Pestalozzi believed that traditional methods of learning relied heavily on a system of inculcation of knowledge. The obvious drawbacks and limits of such a system was the limit of the teacher's knowledge. He developed a system that drew out a child's natural inclination and took into account the child's internal development. See Parna Sengupta (2003), 'An Object Lesson in Colonial Pedagogy', Comparative Studies of Society and History, Vol. 45, No. 1; and also see Parna Sengupta (2011), Pedagogy for Religion: Missionary Education and the Fashioning of Hindus and Muslims in Bengal. Berkeley: University of California Press.

${ }^{52}$ Sengupta, 'An Object Lesson in Colonial Pedagogy', p. 98. 
each other and for their country, strive to quickly gain knowledge to govern their country themselves. ${ }^{53}$

There is no doubt that Ramamurti was part of the national fervour of the movement towards self-rule. Building the nation meant a commitment to these kinds of reforms. For Ramamurti, the promotion of general literacy did not simply imply teaching people the basics of reading and writing but more importantly to create awareness of their new rights as citizens-working towards a 'common citizenship' as he had called it in his memorandum. The Telugu public sphere (consisting of the formation of literary societies, educational institutions, textbook societies, and printing presses that constituted the new sphere of communicative exchange) provided the necessary conditions for the creation of political subjectivities towards a common citizenship. Ramamurti's overall concern in the call for a people's literature was the democratizing of knowledgethat knowledge should be accessible to everyone alike regardless of their class and caste status. Ramamurti repeatedly comments on the reluctance of the traditionally trained scholar (the 'pandit') to teach the lower castes and the untouchables. Also that classical learning was geared towards the upper castes who had greater investments in the literary tradition and its continuity.

A shift to a more pragmatic approach to teaching one's mother tongue would place all classes and castes on the same level playing field in the classroom. Ramamurti writes,

The environment which is common to the Pariah child and the Brahman child, may also be the common subject of study to both, and the language which the latter speaks may be easily taught to the former; thus there may be community of ideas, language, and literature, which will tend to bring the masses in closer union with the classes. ${ }^{54}$

Although Ramamurti uncritically accepts that upper caste dialects would become the written and spoken standard Telugu taught in schools, it is nevertheless important to note the radical nature of his proposal of the centrality of the spoken language as the basis for a new pedagogy that would work to yoke classes together. ${ }^{55}$ Ramamurti points out that just as food, new communicative forms

${ }^{53}$ Gidugu Venkata Ramaurti 'Prajaa saahityam [People's Literature] i p. 103.

${ }^{54}$ Gidugu Venkata Ramamurti, Memorandum on Modern Telugu, p. 21.

${ }^{55}$ Kavita Datla writes of parallel movements taking place in Hyderabad with regard to Urdu. See Kavita Dalta (2009), 'A Worldly Vernacular: Urdu at Osmania University', Modern Asian Studies, Vol. 43, No. 5: pp. $1117-1148$. 
such as newspapers are key ingredients for the sustenance of life in a democratic society. Therefore, all castes, classes and women should be given the opportunity to gain a general literacy to participate in the emergent democratic culture. If we democratize Telugu literary publics, Ramamurti proclaims that all of world literature would be potentially within the reach of the farmer in the field. ${ }^{56}$ The new society that Ramamurti envisions educated in democratic institutions would not heed the exclusivities that existed in the past, especially with regard to access to knowledge. This is crucial to note-the break with the past-in particular a break with past cultural and social hierarchies that traditional feudal society upheld. The generalized literacy he believes fosters a common citizenship. He writes, 'knowledge is being easily disseminated through people's literature and through concise lesson books in order to encourage thinking for oneself and knowing what it means to be an equal citizen in civilized [polite, cultured] society'. ${ }^{57}$ Ultimately, Ramamurti's radical pedagogy was influenced by his deep engagement with the emergent field of linguistics and educational theories at the turn of the twentieth century. ${ }^{58}$

\section{Conclusion}

This paper has been particularly interested in how and why ideas of language, historical change, and progress arose as concerns for the Telugu intelligentsia starting in the latter half of the nineteenth century. The self-conscious advocates of modernity believed in the promise of social transformation of Indian society, which they hoped a capitalist modernity would bring about. There were of course staunch critics of these modernizers and they eventually won the battle over the official promotion of 'spoken language' as a progressive educational policy. The critics of the spoken language movement gathered momentum under the aegis of the Andhra Sahitya Parishad and opposed

${ }^{56}$ Gidugu Venkata Ramaurti, 'Prajaa saahityam [People's Literature], p. 102.

${ }^{57}$ Ibid., p. 103 .

${ }^{58}$ In his writings, Ramamurti conveys a deep engagement with English history. See Ramamurti (1992), Sahitya Vyasalu [Essays on Literature]. Hyderabad: Visalandhra Publishing House. For interesting parallels in educational reform in Bengal especially how the ideas of John Dewey and Maria Montessori came into dialogue with Rabindranath Tagore. See Martha Nussbaum (2010), Not for Profit: Why Democracy needs the Humanities. Princeton: Princeton University Press. 
Ramamurti's ideas of democratizing Telugu, emerging victorious in 1915 . It is vital that the opponents are seen as self-conscious traditionalists-those who sought to establish continuity with what they saw as valuable practices and traditions from the past. ${ }^{59}$ The modernists, on the other hand, accused them of seeking continuities with the socio-political order of pre-colonial south India and upholding the social hierarchies of a feudal past. When Ramamurti wrote, 'The Pandit cannot realize that the literature of a nation, if it is really national, reflects the life of a nation', the pandit, he insisted, is a relic of the old regime, of landed interests, and encouraged cultural stasis. Ramamurti's promotion of spoken language and its place in educational institutions implied a profound disagreement with the exclusivities engendered by pre-modern Telugu literary communities that were sustained by courtly patronage practices.

Telugu intellectuals, such as Ramamurti, reflecting on historical change, progress and modernity at the turn of the twentieth century were not simply imitators of an already formed Western modernity. Rather, they responded from the standpoint of their historical embeddedness in the present to the pace of historical change under colonialism. Ramamurti viewed modernity as a world-historical process-as a universal. Bruno Latour has described two central components of modernity, what he calls the modern constitution: 'the two constitutional guarantees of the moderns-the universal laws of things, and the inalienable rights of subjects' ${ }^{60}$ These are the guarantees that Ramamurti too insisted on for the newly emergent citizen who could now engage in the many publics open to him or her. Whereas south India at the time Ramamurti was writing was by no means a democratic polity, as it was still under British colonial rule, it did witness a flourishing of vernacular public spheres that enabled political engagement for a wider set of actors. In Latour's pithy explanation of the power of modernity, the principles of universality and democratic citizenship are singled out as modernity's anchors. If we take the urge for universality that Latour insists as central to the discourse of modernity, how do we pluralize this urge? What does it mean to pluralize modernities, as suggested at the beginning of this

${ }^{59}$ For an important discussion of 'traditionalist' movements in South Asia, see Barbara Metcalf (2006), Islamic Contestations: Essays on Muslims in India and Pakistan'.' New York: Oxford University Press.

${ }^{60}$ Bruno Latour (1993). We have never been modern. Cambridge, Massachusetts: Harvard University Press, p. $5^{\text {o. }}$ 
paper, as an essential task for those of us working on the histories of postcolonial societies? To pluralize modernities is to acknowledge that there is no singular march towards an Euro-American modernity whilst at the same time to recognize that there are shared components of modernity between European, American, and postcolonial societies. This is to say that the instantiation of capitalist modernity in different geographical and historical locations gives rise to different social and political institutions.

Ramamurti's embrace of modernity's guarantees displays the power of the discourse of modernity and his socio-political reform practices that were enabled by it. The emergent Telugu publics gave rise to rational-critical debate over social and cultural hierarchies thereby ushering in new forms of politics. Cultural critic Michael Warner suggests that 'when people address publics, they engage in strugglesat varying levels of consciousness, from calculated tactic to mute cognitive noise-over the conditions that bring them together as a public'. ${ }^{61}$ Warner adds weight to Habermas's classic definition of the public sphere as a sphere of rational-critical debate by drawing attention to the struggles over identity that social and cultural movements enable in the public sphere. He also warns that contrary to how Habermas has been interpreted, there is no singular unity to a public sphere in any given society. There are often multiple publics within which these contestations take place. In nineteenth century south India, the expansion of the public sphere did not singularly produce social and cultural movements in a united front in opposition to the colonial state. Rather, the expansion of print and new communicative forms gave rise to passionate contestations over existing cultural and political hierarchies (caste, gender, religious difference) whose primary target of critique and reform was not simply the colonial state. For instance, Telugu publics enabled fierce contestations over the place of language in modern institutions between the traditionalists and the modernizers. Whereas the former defended the continuing currency of pre-colonial linguistic and aesthetic practices, Ramamurti's contention was that new ideas of democratic citizenship and the liberatory potential of political modernity required radical proposals to reform language practices through modern schooling.

${ }^{61}$ Michael Warner (2002), Publics and Counterpublics. New York: Zone Books, p. 12. 